IZA DP No. 6355

Celebrating 150 Years of Analyzing Fertility Trends in Germany

Michael J. Kendzia

Klaus F. Zimmermann

February 2012

Forschungsinstitut zur Zukunft der Arbeit Institute for the Study of Labor 


\title{
Celebrating 150 Years of Analyzing Fertility Trends in Germany
}

\author{
Michael J. Kendzia \\ $I Z A$ \\ Klaus F. Zimmermann \\ IZA and University of Bonn
}

Discussion Paper No. 6355

February 2012

IZA
P.O. Box 7240
53072 Bonn
Germany

Phone: +49-228-3894-0

Fax: +49-228-3894-180

E-mail: iza@iza.org

\begin{abstract}
Any opinions expressed here are those of the author(s) and not those of IZA. Research published in this series may include views on policy, but the institute itself takes no institutional policy positions.

The Institute for the Study of Labor (IZA) in Bonn is a local and virtual international research center and a place of communication between science, politics and business. IZA is an independent nonprofit organization supported by Deutsche Post Foundation. The center is associated with the University of Bonn and offers a stimulating research environment through its international network, workshops and conferences, data service, project support, research visits and doctoral program. IZA engages in (i) original and internationally competitive research in all fields of labor economics, (ii) development of policy concepts, and (iii) dissemination of research results and concepts to the interested public.
\end{abstract}

IZA Discussion Papers often represent preliminary work and are circulated to encourage discussion. Citation of such a paper should account for its provisional character. A revised version may be available directly from the author. 
IZA Discussion Paper No. 6355

February 2012

\section{ABSTRACT}

\section{Celebrating 150 Years of Analyzing Fertility Trends in Germany*}

Ever since the very beginning of the Journal of Economics and Statistics, population economics has featured prominently in the Journal. Fertility naturally plays an important role in population economics. Its size has decreased significantly from the 1900s. Long timeseries regarding fertility and basic trends in Germany are documented and analyzed. We identify three different explanatory approaches for the decline in fertility, according to which the various articles of the Journal related to this area are categorized. The paper also investigates previous fertility studies published by the Journal since the beginning. It points out that several articles anticipated subsequent research directions in the area of population economics at an early stage. In addition, significant contributions were made in terms of further developing existing knowledge. Thus, the Journal has helped to expand the research area of population economics.

JEL Classification: J10, J11, J13

Keywords: fertility, total fertility rate, Malthus, self-regulation, Q-Q trade-off

Corresponding author:

Klaus F. Zimmermann

IZA

P.O. Box 7240

53072 Bonn

Germany

E-mail: Zimmermann@iza.org 


\section{Introduction}

"People will always have babies" was what the German chancellor Konrad Adenauer said in 1957, when he defended the reform of the German pension system to a payas-you-go scheme. With that statement he destroyed the arguments of those who doubted that the system - based on the so-called generation contract - would last forever. In the same year the total fertility rate in West Germany was 2.36 children per woman, but by 2010 that rate had fallen to only 1.39 (Destatis 2012b). While Adenauer did not consider this a problem, demography has proven him wrong. This is why a proper understanding of population economics is so important.

Since its beginning in 1863 the Journal of Economics and Statistics, founded by Bruno Hildebrand (1812-1878), has taken this research topic comprehensively into account. This article seeks to take stock of the development of population economics, focusing on the discussion on fertility, in particular with regard to early articles of the Journal. To do this, we aim to examine both the explanatory variables and the development of the understanding of the population process after what Walt Rostow (1969: 4ff.) refers to as the take-off of industrialization in Germany, which took place between 1850 and 1873 . Fertility and mortality undoubtedly constitute the essential growth components regarding the development of the population. In the present paper we focus primarily on the development of fertility in Germany, but without neglecting to investigate the mortality rates.

The outline of the paper is as follows. The next section provides an overview of the long time-series and trends of fertility. The analysis includes also a discussion of the recent situation in Germany. Thereafter, we present and discuss the respective articles of the Journal in chronological order taking into account three explanatory approaches or theories. The paper ends with conclusions.

\section{The long-term German demographic development}

This section analyzes the economic factors influencing the changes of fertility over time. Many European countries including Germany experienced a phase of demographic transition from 1800 to 1900 . This phenomenon is usually defined as the transition process from (both) high to (both) low mortality and birth rates (Thompson 1929; Notestein 1945). This transition usually starts with a decreasing mortality rate, which after some time is followed by a decline in the fertility rate. Associated with these demographic changes, as Figure 1 shows, is the per-capita income level, which grows noticeably from the 1950s - denoting an economic transition (Cervellati/Sunde 2007). The graph shows that births per 1000 inhabitants decreased drastically. The same is true for the child mortality rate, which is not shown here. Figure 1 indicates a negative correlation between the birth rate and national income per capita, at least after 1950. 


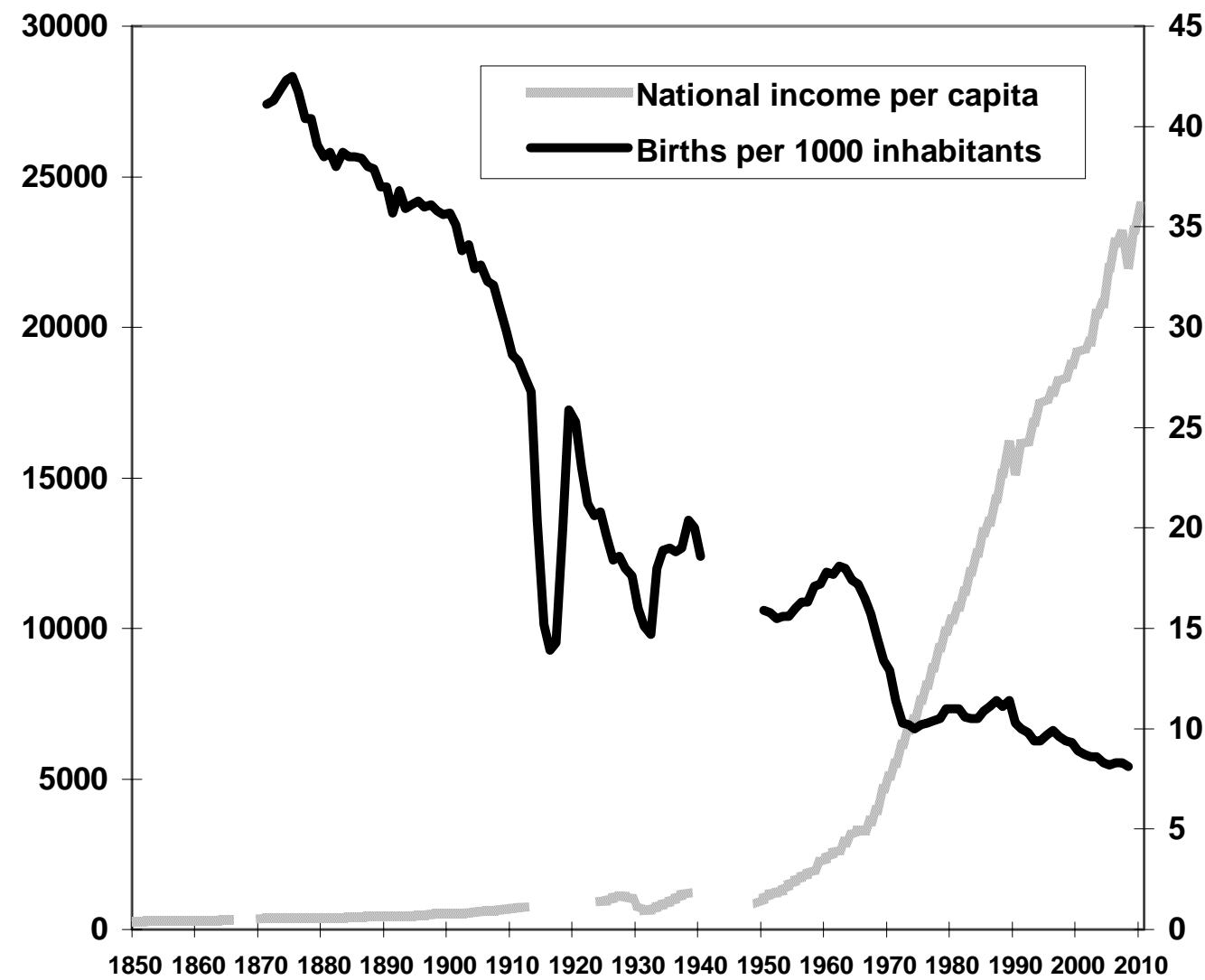

Source: Hoffmann/Müller (1959: 39ff.); Destatis.

Note: 1859-1913: German Empire, 1913 including Alsace-Lorraine, 1925-1938: German Empire until 1934 without Saarland and since 1935 including, 1950-1959: Federal Republic of Germany without West Berlin and Saarland. The data from 1950-1990 are from Destatis for the Federal Republic of Germany without East Germany and after 1991 for Germany. National income per capita in euro (for previous years converted). The incomplete graph is a result of an absence of data at the end of World War II.

Figure 1 National income per capita and births per 1000 inhabitants In order to complete the long time-series, we present the development of the total fertility rate from 1870 to 2010 . As a reference, we also measure and present the replacement rate over time, which is the level of fertility required to ensure a constant population. In this calculation we do not consider migration. As Figure 2 shows, about 40 years after the beginning of the Journal in 1863 the total fertility rate started to decrease significantly. The first drastic low occurred during World War I (1914-1918). Afterwards, the total fertility rate recovered again, peaking around 1920 at a little less than 3.5, but reached another low only a few years later during the Great Depression. Thereafter the rate recovered again quickly, before diminishing sharply with the beginning of World War II to a new record low by the end of the war. After a rise in the birth rate between 1950 and 1960 the rate increased strikingly before reaching a new low in the early 1970s and remained relatively stable up to 2010. 


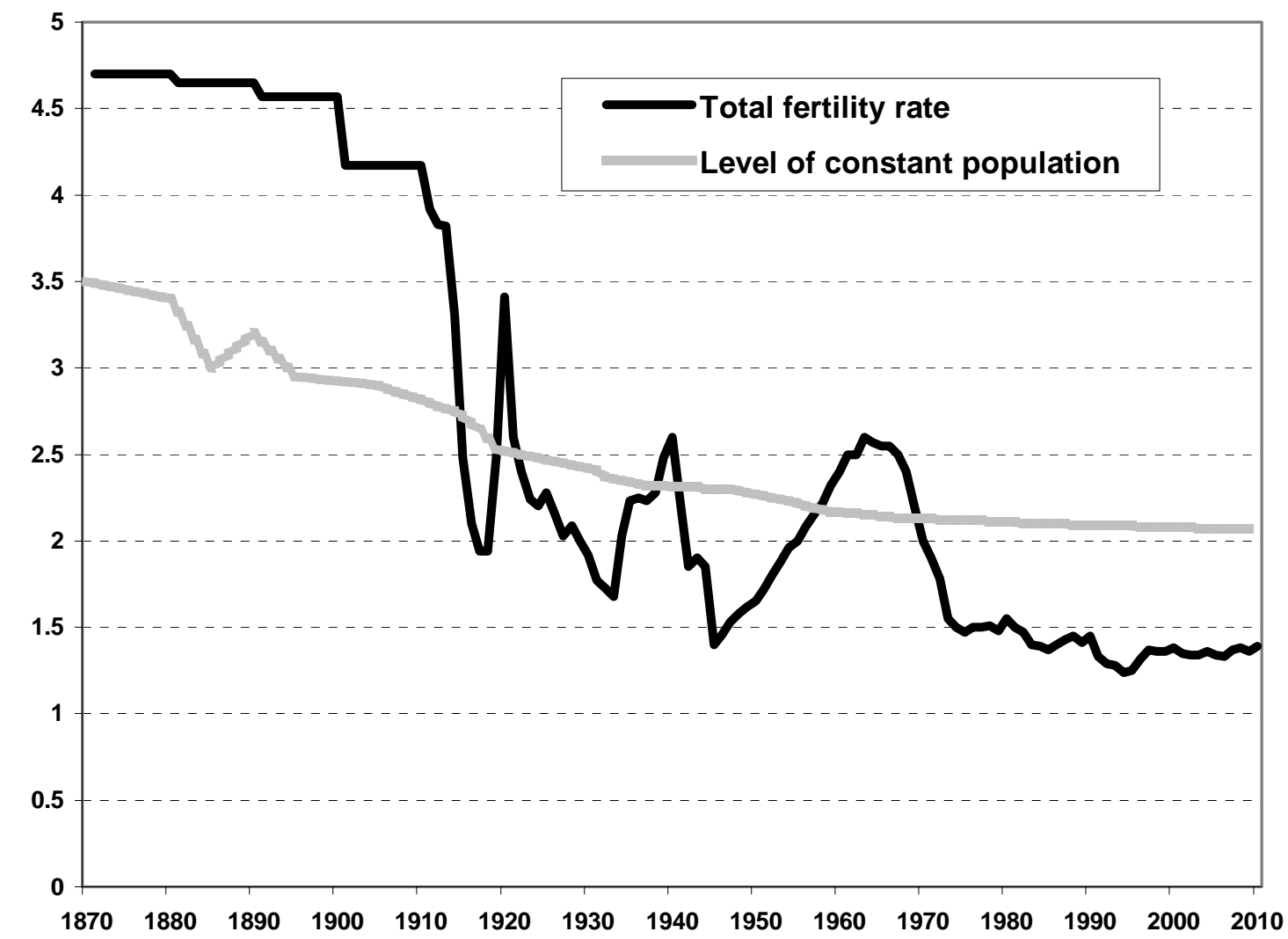

Source: Bundesinstitut für Bevölkerungsforschung (2011).

Note: For several years no data were available. To create a long series, intermediate years were estimated for Germany.

Figure 2 The long decline of the German total fertility rate from 1871-2010

Figure 2 shows that the fluctuations around the trend diminished over time. Since the middle of the 1970s the course of the total fertility rate seems to have remained relatively stable.

Shortly after the first publication of the Journal the average life expectancy at birth was approximately 34 years for men and 37 for women (Ehmer 2004: 34), whereas a man born in 2008/2010 is likely to live for about 77.5 years and a woman 82.6 (Destatis 2012a). In 2010 the total fertility rate in Germany was roughly 1.4 on average (Destatis 2012b). Moreover, since 1983 the rate has remained below 1.5 children per woman (OECD 2011). During the first years of the Journal, the average total fertility rate after the formal reunification of Germany (Reichseinigung) in 1871 was roughly 4.7 and thus significantly higher compared to 2010.

\section{The contribution of the Journal to population economics}

During our investigations we identified three different explanatory approaches for the decline in fertility, according to which we will categorize the various articles of 
the Journal related to this research area. The first approach was made by the founder of population economics, Thomas R. Malthus (1766-1834). The English economist painted a rather gloomy picture of the near future in view of the population. His 'Essay on the Principle of Population' (Malthus 1798) was one of the first on population economics which received a great deal of attention.

Table 1 Relation between population and food growth according to Malthus

\begin{tabular}{|l|r|r|r|r|r|r|r|r|r|}
\hline & \multicolumn{10}{|c|}{ Annual intervals } \\
\cline { 2 - 10 } & 0 & 25 & 50 & 75 & 100 & 125 & 150 & 175 & 200 \\
\hline $\begin{array}{l}\text { Total pop- } \\
\text { ulation }\end{array}$ & 1 & 2 & 4 & 8 & 16 & 32 & 64 & 128 & 256 \\
\hline $\begin{array}{l}\text { Means of } \\
\text { sustenance }\end{array}$ & 1 & 2 & 3 & 4 & 5 & 6 & 7 & 8 & 9 \\
\hline
\end{tabular}

Source: Esenwein-Rothe (1978: 58).

Malthus assumed that the total number of the population would grow in a geometric series, which meant the number would double every 25 years. On the contrary, the means of sustenance could only be enhanced by arithmetical progression (see Table 1). The population would thus grow more rapidly than food production. Further growth in the population could not be supported by the food supply and would lead to impoverishment or death from starvation (Esenwein-Rothe 1978: 58). Thus, the fear of overpopulation and food scarcity, introduced by Malthus, constitutes the first explanatory approach in the area of population economics.

The second approach was developed by Lujo Brentano, Gary Becker and Jacob Mincer (Brentano 1909; Becker 1960; Mincer 1963). This approach is closely related to the rational choice theory dealing with trade-offs between goods and opportunity costs. This theory is based on utility maximization and takes into account in various forms the costs of raising children, the value of time, the costs for education, the participation of women in the labor market as well as the impact of uncertainties on the labor market. It creates a potential for a non-linear budget constraint that generates an impact of income on fertility that switches from positive to negative with rising income. Rising living expenses and female wages are negatively related with fertility.

The third explanatory approach is circumscribed by self-regulation. Ronald Freedman (1975) offers the explanation that fertility reacted to the increase of child survival in a more or less homoeostatic way. This means that self-regulation played a strong role during 1875 and 1960 . According to this approach, the phenomenon of the decline in fertility can be attributed to a regulatory circuit. Hence, fertility adapts to a decline in the child mortality rate and a natural number of children is reached. In turn, when child mortality is high, more children are raised. This approach is not linked with the rational choice theory, but it rather contains a leveling off in terms of fertility. 
Ever since the very beginning of classical economics, population problems have played an important role in this emerging research area. At the time of mercantilism, which represented the dominant economic doctrine across Europe from the $16^{\text {th }}$ to the $18^{\text {th }}$ century, people assumed that the strength of a country largely relied on the number of soldiers. To obtain a large army, a country had to strive for a large population. The German pastor, statistician and demographer, Johann P. Süßmilch (17071767) believed population growth to be the 'happiness of a country'. The prosperity of a nation would, according to the mercantilist conception, benefits enormously from an increasing population by stimulating social and economic development. It was assumed that demographic growth would contribute to consolidating the position of the ruling class (Overbeek 1974: 30).

In order to paint a realistic picture of the past, it should be noted that at the beginning of the $19^{\text {th }}$ century most women in Germany died at an early age. Although lifespans were shorter, there was an average of five births per married woman. However, during that time we have to differentiate between the number of births and the number of children. In the middle of the $19^{\text {th }}$ century only half of all children born in Germany reached adulthood. Not until the course of the $20^{\text {th }}$ century did the number of births and that of children start to converge. It was at the turn of this century when generations of women stood on the verge of a decline in the fertility rate. Thereafter, the average number of children per woman decreased dramatically from nearly 5 to around 2 (Ehmer 2004: 34-44). With the growing acceptance of how germs spread disease, more emphasis was put on hygiene, which constrained the spread of diseases and contributed to a rise in life expectancy. Factors contributing to lower mortality rates amongst children included the declining price of food relative to wages, and better quality and diversity of food. This was especially true of food bought from urban markets. Moreover, better housing together with the expansion of welfare systems greatly improved the medical and nutritional conditions for the vast majority of people (Schultz 2009).

At the end of the $19^{\text {th }}$ century Reich Chancellor Otto von Bismarck gradually introduced social legislation in Germany, starting with accident insurance in 1884 . This insurance was created in order to protect workers against basic risks. The emergence of the social security system at the end of the $19^{\text {th }}$ century established a welfare system which began to expand in the following years and provided a safety net from risks such as accidents, poverty, aging and illness (Kendzia 2010a). However, this was not the first legal provisions of this kind. The Regulativ über die Beschäftigung jugendlicher Arbeiter in Fabriken was one the first legal measures which protected workers and came into force in 1839 . The result was a major step towards a ban in Prussia on child labor (aged younger than 10). Several other factors also played a role, including the decreasing demand for unskilled workers as a consequence of rapid technical progress, and a stronger enforcement of the compulsory school attendance which had existed throughout Prussia since 1717 (Kendzia/Pierenkemper 2010). Through the stronger enforcement of the compulsory school attendance, fewer individuals were joining the workforce. 
This, in turn, resulted in a relaxed situation in the labor market, which went hand in hand with a rise in living standards across Germany (Zimmermann 1988). Most parts of Europe during the 19th century were shaped by a new and irreversible process which had begun leading to the single most sectoral structural change in the economic landscape: industrialization. The share of people working in agriculture decreased, and more and more people began to work in new industries such as mining and steel manufacturing or later in the chemical and electrical industries, which soon started to gain international reputation.

In the first years of the Journal the economist and statistician Hans von Scheel (1839-1901), an assistant of Hildebrand at the statistical office in Jena, showed that the wealth and growth of the population would be closely related to the quantity of available resources, such as means of sustenance (e.g. food). According to Scheel, it would be the task of statistics to recognize and verify the degree of the dependence the population had on comestible goods. He referred to an early study carried out by the French demographer Louis Messance (1734-1796) on the relation between grain prices and changes in the mortality rate. ${ }^{1}$ Messance (1767) had shown a time-series including the average grain prices and compared those with the mortality rate over time. He found that the mortality rate was lower when grain was cheaper. After presenting further studies on this issue he concluded that there was little point investigating the manner further because showing that grain prices influence the mortality rate could be displayed by following simple common sense - without any help from statistics. Scheel then investigated the prices of grain, potatoes and meat in the small duchy of Altenburg from 1835 to 1864 . However, since the consumption of meat relative to grain or potatoes - was small for large parts of the population, he decided to concentrate on the development of the price of grain and compared its course with the number of births. He showed a contrary development of the price of grain and fertility, i.e. that a high price for grain resulted in lower births in following years (Scheel 1866: 176ff.).

A few years after Scheel's analysis of the price of grain and its close relation to the mortality rate, the economist, and later rector of the University of Strasbourg, Georg Friedrich Knapp (1842-1926) investigated the mortality rate for the city of Leipzig from 1751 to 1870 . He found that the mortality rate of children 12 months and younger was 0.223 , which meant that from 1000 children approximately 223 had died during their first year. By contrast, this rate was 0.144 for children between 1 and 10. Knapp argued that compared to earlier years both rates had already decreased and concluded that this could in particular be attributed to an improvement of health care, with better hospitals, an approved type of construction of cities as well as better household furnishings (Knapp 1873a).

Thus, in the literature there already existed agreement over improvements in terms of urban public health infrastructure leading to increasing living standards. For instance, investments and regulations concerning water supply and sanitation had had

1 Recherches sur la population des genéralités d'Auvergne, de Lyon, de Rouen et de quelques province et villes du royaume avec des reflexions sur la valeur du bled tant en France qu'en Angleterre depuis 1674 jusqu'en 1764 par M. Messance (Louis Messance), Paris 1767. 
a huge impact on the quality of life. The growing standard of living can be interpreted as a consequence of a general process that had been occurring during the $19^{\text {th }}$ century: urbanization. It describes the migration from larger parts of the population from the countryside to steadily growing cities. As a result, more and more of those agglomerations attracted an increasing number of workers. Around 1913 the general employment in industries in Germany exceeded the employment in agriculture for the first time (Kendzia 2010a: 6).

The process of urbanization was also documented by several authors of the Journal (e.g. N.N. 1871: 135ff.; Seutemann 1906: 88). Scheel (1874: 1ff.) indicated that the urbanization went hand in hand with an increasing rate of women's employment. Moreover, he denoted that they were becoming less active in the field of domestic work. As Scheel put it, women were being driven out of their traditional sphere of work. A later article examined the further growth of the population and in particular considered the high fertility rate in industrial areas, which was attributed to the large number of children working class families had (Rohr 1891: 118f.).

Prinzing (1899: 581) gave a truly comprehensive account of child mortality across Germany. He analyzed the development of the child mortality rate within European countries over time. According to him, favorable economic conditions would result in higher fertility rates, but he failed to substantiate this. Prinzing's elaborations and assumptions were closely related to Malthus' treatise and can thus be attributed to the first category of our explanatory approach. Similar to Malthus, his assumptions would have led to an enormous rise in population by an increasing national income per capita (as Figure 1 shows). He was proved to be wrong shortly after the turn of the $20^{\text {th }}$ century.

A later author of the series contributing to the discussion on the development of fertility, Karl Seutemann (1907: 293ff.), observed a decline in the fertility rate between 1890 and 1905. He denoted that a decline in the mortality rate would lead to two growing parts of the population: on the one hand, the non-fertile cohort such as the very young, and on the other hand, the old. He went on later to discard this notion. He pointed out that a certain mechanism of self-regulation would imply decreasing fertility rates. He concluded that a decline of the fertility rate was mostly associated with food shortages resulting from higher life expectancies as well as the decreasing mortality rate. Consequently, people would raise fewer children than in the past (Seutemann 1907: 293ff.). With this, Seutemann (1907) relates to the first category of the three identified explanatory approaches.

The German economist and social reformer Lujo Brentano (1844-1931) found a direct and negative correlation between welfare and matrimonial fertility. In addition to Malthus, who argued that sexual abstinence, vice and misery all impeded fertility, Brentano (1909) suggested that physiological reasons as well as the separation between sexual drive and reproductive behavior would also affect fertility. However, we will not elaborate on the physiological aspect in this paper, since we argue that the decisive factors influencing fertility have always been primarily of an economic nature. According to Brentano (1909), the decline of the willingness to procreate was 
due to different activities from which the household could choose and an enhanced quality of child care. The concept of choice between different activities by respecting the utility maximization, the time costs of bringing up children as well as the quality of life for children can all be interpreted as an important step in the area of population economics (Zimmermann 1989: 474ff.). Since Brentano (1909) stresses household choice he should be considered as a representative of the rational choice theory and belongs to the second category of the explanatory approaches.

In 1913 Henriette Fürth (1861-1938), who later became the first woman to join the German Society for Sociology, noted in the Journal that a decline in fertility would constitute a major social problem and indicated that with increasing costs of the standard of living - and growing expectations as a result - fewer children would be born. With regard to higher fertility within working-class families compared to other social classes, she argued that a rise of food prices would also contribute to higher costs of living. Since fertility rates had decreased among both the poor and the rich, she also traced the decline back to more sophisticated individual, cultural demands (Fürth 1913: 721ff.). However, Fürth follows the second explanatory approach by exhibiting higher demands which would lead to higher costs to keep the standard of living. With that, not only Seutemann (1907) but also Fürth (1913) had already identified key elements of the quality-quantity trade-off, which is later further discussed by Becker. Interestingly, Fürth (1913) showed that the administration was deliberately not spreading contraception among the vast majority of the population but instead distributing it solely to members of the German navy. The government wanted unrestrained population growth in order to strengthen military power (Fürth 1913: 747ff.). A possible reason why sailors are given contraception is most probably to protect its sailors from possible diseases. However, this is not speculated by Fürth.

During World War I fertility declined, but Fürth did not consider reasons for this phenomenon in her article (Guradze 1916: 550ff.). As P. Kollmann (1915: 251f.) had argued one year earlier, the only cogent reason for the further decline in fertility could be associated with the continued reduction in child mortality. If we follow his argument, then most people in society had started to anticipate the converging of the number of births and the number of children, which was due to a decline in child mortality rates. Similar deliberations were shared by Karl Oldenberg (1923: 315ff.), who dealt explicitly with the connection between fertility and child mortality. Both deliberations dealing with anticipation that can be seen in connection with the third explanatory approach 'self-regulation'. In the $19^{\text {th }}$ century the number of births and the number of children were divergent. Due to a decline in the mortality rate in the $20^{\text {th }}$ century, those numbers converged. Self-regulation thus meant that people anticipated these changes and adapted the number of children accordingly.

Ernst Günther dealt with the issue of declining fertility and its potential impact on the unemployment rate in an article in 1931. He examined a period of around 15 to 20 years during the demographic transition. The paradox he formulated was that fewer births - and with that fewer workers - would lead to higher unemployment (Günther 1931). Adolf Wagner adopted this idea in his article of the same title. He believed that if the dependence were to exist, there would be something - in the 
style of the demographic transition - like demographic unemployment (Wagner 1980).

Following the rise to power by the National Socialists in 1933 their ideology including the role of women as mothers and housewives could soon be observed across society. After the Great Depression, during the early 1930s, the regime started replacing female employment with male employment and promoted female activities in the area of private households and agriculture. According to Mackenroth (1934: 205), this measure aimed at stabilizing the wage level. As we can see from Figures 1 and 2, there was a noticeable increase in fertility. Michalke (1935: 438ff.) noted that during the Great Depression the spread of female employment was due to the fact that female labor was cheaper. In the following years possible female employment was considered as a 'reserve'. In 1936 the official office responsible for the use of female workers - Frauenamt der Deutschen Arbeitsfront - prepared women for their later roles as mothers and housewives rather than for the labor market (Willeke 1936: 197).

After reaching full employment in 1936 the regime first tolerated and afterwards supported female workers. When labor shortages occurred, the interest of the National Socialist regime to promote female employment grew rapidly from 1942 on. This resulted in obligatory work for women in 1943 (Kendzia 2010b). Interestingly, in 1937 Ungern-Sternberg (1937: 471ff.) examined the development of the economic situation in parallel with fertility. He presented a theory which compared the relatively low fertility with the 'state of emergency' in which individuals found themselves. The reason for this assumed state was that most people thought they could not afford to have children. Furthermore, in his investigation he suggested that the reason for the decline in fertility would stem from self-imposed 'artificial birth restriction'. This behavior was, according to Ungern-Sternberg, due to the intention of many people in society to sustain prosperity for the later generation. Hence, he belongs to the second category within this paper. Birth control in order to ensure a higher living standard for future generations reflects a trade-off which can be interpreted as a rational choice. His explanations are early indication of an idea which would later be described as 'fertility control' by the French demographer Louis Henry in the 1950s. Fleury/Henry ((1956)) stressed that fertility control would result in fewer children because households would avoid further births after a certain number of children had been reached (Coale/Watkins 1986: 9). And indeed, this argumentation raises again the importance of the formulated trade-off in a household, which states that human beings should behave or act rationally. Accordingly, the strong desire for restricted births corresponded directly to the social and economic change taking place at that time (Pollack/Watkins 1993: 468f.).

In 1941 Zwiedineck-Südenhorst (1871-1957) (1941: 161ff.) noted that in previous centuries the fear of overpopulation often occurred and thus rather Malthusian scenarios were drafted. However, in recent years, as he observed, rather the fear of depopulation would arise. With Zwiedineck-Südenhorst the Journal experienced a caesura in terms of publishing articles on fertility issues. The Journal's interest in population economics decreased soon after World War II. We can say that during this pe- 
riod more emphasis was generally put on theoretical developments in economics, but discussions on fertility vanished from the scene. According to Kurz, World War II and a massive increase in the fertility rate in the following years led to this standstill (Kurz 1982: 235f.).

This changed with stagnating and later decreasing fertility rates in the beginning of the 1970s in many industrialized countries. Jacob Mincer (1922-2006) (1963) further developed the decision-making process within households by introducing two important factors. Firstly, he introduced the time costs of raising children, and secondly, he argued that the female labor force supply and the wish to have children are both part of the decision-making process within the family. In doing so, Mincer applied the concept of opportunity costs to the issue of raising children (Zimmermann 1988: 123; Zimmermann 1989: 469). In the sequel, it was possible to predict a decline in fertility and a rise in female work participation as the outcome of joint decision making driven by a relative increase of female wages in comparison to male wages.

The next groundbreaking contribution to model the decline in fertility was Becker's attempt to model home production within the so-called quantity-quality ( $Q-Q$ ) trade-off (Becker 1981/1991). This approach pointed out that the Malthusian model had missed the connection that with increasing income more and more emphasis was put on child quality. The child $Q-Q$ trade-off between fertility and education is generally described as the choice between the quantity of children and the quality of human capital invested in each child. Becker showed that the $Q-Q$ trade-off is closely related to income, prices as well as tastes (Becker/Cinnirella/Woessmann 2009). Zimmermann (1985) has shown that the complex quantity-quality approach of Becker can be replaced by simply assuming that child material expenditures ("child living expenses") are rising with the consumption level of the parents. This child living expenses approach leads to the same conclusions concerning a negative impact of rising income on fertility.

As another representative of the rational choice theory, Ingeborg Esenwein-Rothe (1911-2002), dealt with population forecasting models and their limits in 1978. She examined the different developments concerning fertility across the world. She investigated not only the issue of overpopulation in developing countries but also the deceasing fertility, and wrote of the fear of the death of an entire nation. EsenweinRothe (1978) also described the reasons for the increasing standard of living during industrialization by highlighting how the railway and steamships had expanded means of sustenance. At the same time the transparency of the market had improved through modern telecommunications. She spoke of a cultural change in awareness of future generations. Fertility would go hand in hand with the increasing standard of living, which meant that the size of family would adapt to the financial and time resources of the individuals according to their social conditions and desires (Esenwein-Rothe 1978).

Meanwhile, the family of four of two parents and two children had become the dominant family structure in society. During the time when national ideas were sweeping across Germany, this dramatic decrease was heavily debated and criticized as the 
possible death of the nation - and later, assuming an ever more dramatic scenario during the years of the National Socialist regime, the death of the German race. By World War I the total fertility rate had reached an all-time low, which recovered afterwards, but fell once again to a new low during the Great Depression and at the end of World War II. As Figure 2 shows, the 1950s and 1960s witnessed a baby boom, with the total fertility rate rising to nearly 2.5 . This can be linked with the German economic miracle which took place until the first recession after World War II, in 1966 to 1967. After that period a short and dramatic decline in fertility occurred until the early 1970s, when the decline stabilized. The development of the total fertility rate in West and East Germany until 1970 remained more or less the same. Only in the second half of the 1970s did the rate increase in East Germany, whereas the rate in the West remained stable at 1.4 (Ehmer 2004: 44-46).

Another contribution in the Journal, which was made by Adolf Wagner, dealt with a book dealing with the decline in fertility (Dinkel 1985). Wagner pointed out that most people worked in agriculture prior to industrialization. During that time children were often employed as workers on the family farm (Wagner 1985: 544). Thus, child work diminished during industrialization and fewer children were born. The gloomy scenario of Malthus regarding overpopulation did not materialize in developed countries because one of his key assumptions proved to be wrong. Malthus failed to consider that technical progress would increase farming yields so greatly, which meant that the increase in food supply outstripped the demand.

Furthermore, Malthus suggested a positive correlation between income and fertility (Zimmermann 1988: 121f.). Due to the implementation of a social security system, the social benefit of children decreased. At the same time, the costs of raising children increased. Matthias Bletzinger and Uwe Walz (1989) extended the theoretical model of fertility by Zimmermann (1985) to explain the empirically observable negative relationship between income and fertility. They showed that in particular the social status of the parents determines the essential inputs for the children. Olaf Hübler (1991) added that women would earn on average less than men. He dealt with the causes of gender wage discrimination and gender dependent earnings. The article did not discuss the economic factors influencing fertility, however. Assenmacher and Wenke (1993) referred to Becker's model of the household, which is not only consuming but also producing. Both authors reported that the service sector has risen constantly across industrialized countries. To explain this growth, they indicate the shift from home production to market production in terms of services as a consequence of increasing labor market participation by women. This trend is displayed in Figure 3. 


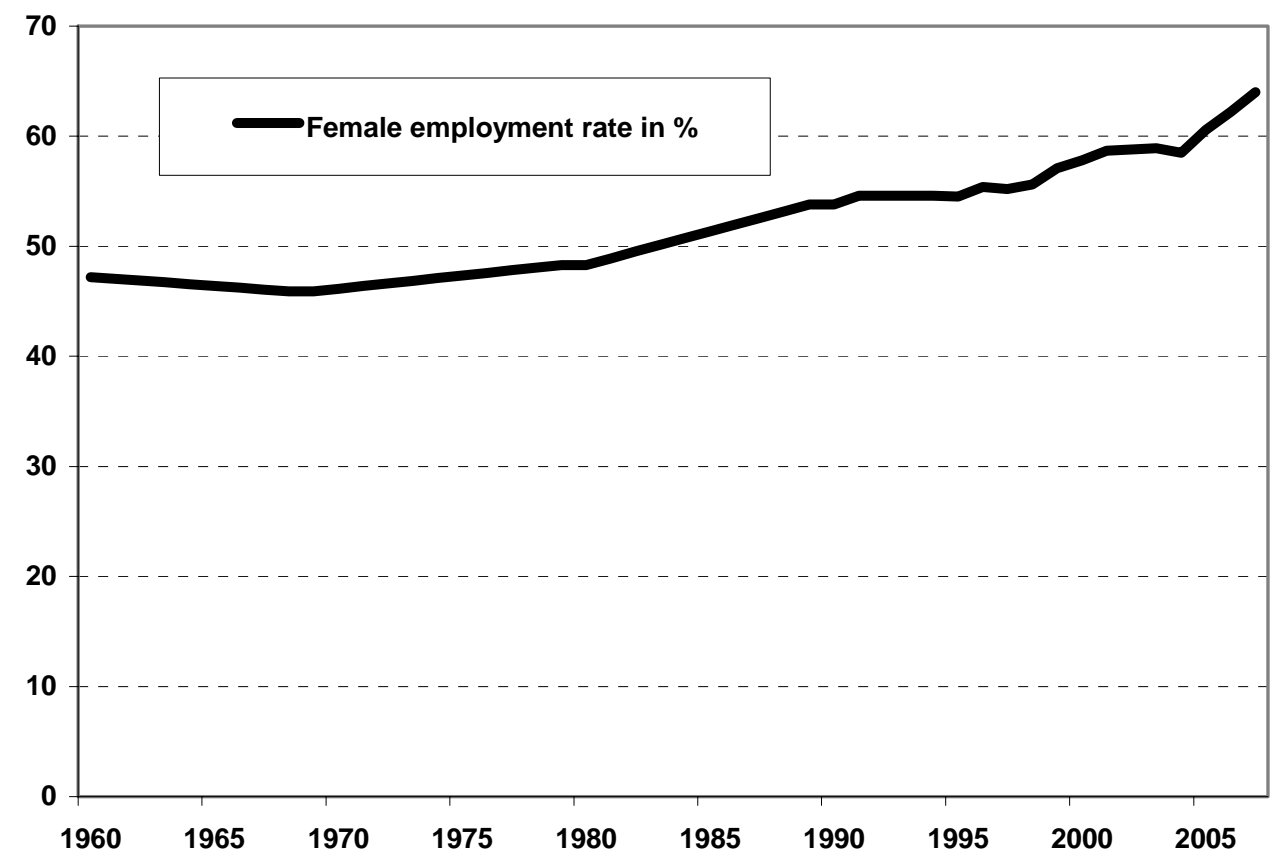

Source: Statistisches Bundesamt 2008, Arbeitskräfteerhebung der EU.

Note: Rate of the labor force in population in the age from 15 to 64 years; 1960-1989 West Germany, From 1990 Germany; interpolated from 1960-1990 every ten years and from 1990 on each year.

Figure 3 Female employment rate in \% from 1960-2007

More than thirty years after Mincer's contribution on the family, Galor and Weil (1996) created a model which was based on the idea that increasing capital per worker would imply a rise of the relative wage of female workers. This, in turn, would lead to a reduction in the size of the family, which would imply that childrearing activities and female labor supply would substitute each other (Galor 2005). Figure 4 shows the development of women's income in percent by men's. Similar to the participation rate of women in the labor market, women's relative income has risen relatively stable since the 1960 s. 


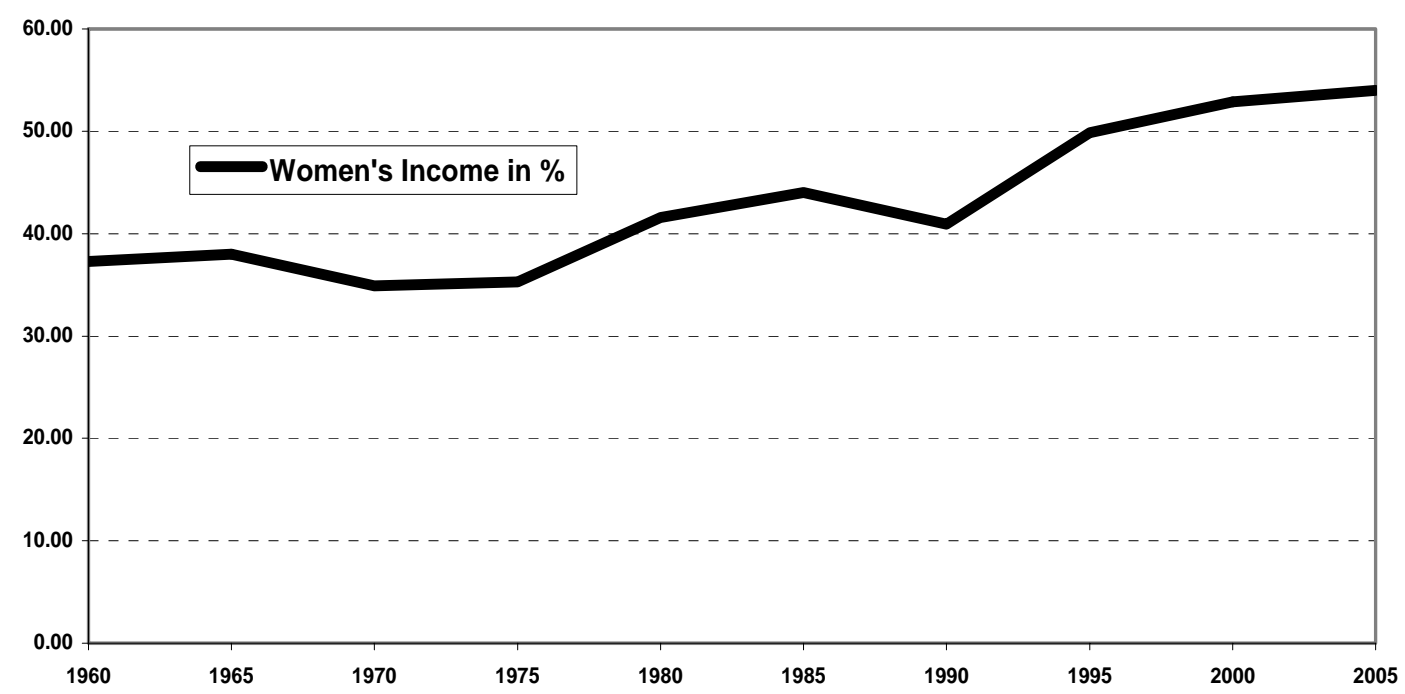

Source: BFSFJ: Gender-Datenreport - 1. Datenreport zur Gleichstellung von Frauen und Männern in der Bundesrepublik Deutschland München, November 2005: 219.

Note: Percentage of women's income by men's income. The income is cumulated on the basis of the average annual earning points and the average insurance years when retiring. From 1990 on it is weighted by the proportion of East (about 20\%) and West Germany (about $80 \%$ ).

Figure 4 Development of women's income in \% of men's income

Althammer and Wenzler (1996) exhibited that the decision on the allocation of working time would take place within households and dependent on the husband's wage. The total fertility rate in the East Germany was the lowest in the world at 0.77. Eberhard Schaich (1998: 94-105) stressed that from 1991 to 1995 the rate remained constantly under 1 . He offered several explanations for this, such as a pessimistic assessment of the future of young women because of the new political situation and many job losses during that period. In addition to new alternatives to the tradition family pattern, new job opportunities and consumption possibilities had emerged. After some time, an alignment to the demographic situation in West Germany began to occur.

Kleinhenz (2004) dealt with the consequences of the demographic change. He stressed the impact of the sudden drop in birth rates due to the birth control pill. Further explanations are associated with balancing the different demands between the workplace and family life, since most women tend to have fewer children at a later age (Kohler et al. 2002). The increase in life expectancy and the technological change taking place is accompanied with higher wages. This, in turn, leads to more educational attainments across the population, in order to acquire time-intensive human capital (Cervellati/Sunde 2007). According to recent research in this area, the rational choice approach forms a conceptional framework which is likely to be consistent and give an account of both the economic and fertility transition (Cervellati/Sunde 2007). It appears that from today's point of view, the basic changes in mortality and fertility are dependent on the reallocation of family resources (Schultz 2009). 
Furthermore, the latest research shows that even prior to the demographic transition, the Q-Q trade-off had existed (Becker et al. 2009). There has been an extensive empirical literature on both human capital and family economics in recent years in the area of population economics. The majority of that literature concludes that factors such as marriage, work, wages, schooling as well as a high labor force participation rate of women all affect fertility to a great extent (Browning et al. 2011).

\section{Conclusions}

Deliberations on population economics in Germany have lost nothing of their importance, as a closer look at the trends and the number of works in the Journal regarding fertility confirms. As we have found, the three explanatory approaches (i.e. Malthus' early contributions, the rational choice theory and self-regulation) have all appeared in the Journal in some way over time. Whereas Malthus' idea of food scarcity due to overpopulation was mentioned 1899 for the last time, treaties dealing with the explanatory approach of self-regulation appeared even in 1915 (Kollmann) and 1923 (Oldenberg). Nevertheless, the concept of self-regulation was not noticed in the Journal in the aftermath. The rational choice approach became the dominant stream to explain the course of fertility in the area of population economics. The approach which is based on the rational choice theory seems to provide a plausible answer to many questions raised in this article. It appears that the benefit of children was higher before the demographic transition. After the end of the transition process, the decline in the child mortality rate and the wide establishment of a social security system led to a diminishing benefit of children. At the same time, to ensure children the same standard of living, parents faced increasing costs of raising children. However, since the 1970 s the total fertility rate has remained relatively stable - but at a much lower level.

\section{References:}

Althammer, J. and S. Wenzler (1996), Intrafamiliale Zeitallokation, Haushaltsproduktion und Frauenerwerbstätigkeit, Jahrbücher für Nationalökonomie und Statistik, Bd. 215: $398-418$.

Assenmacher, W. and M. Wenke (1993), Haushaltsproduktion, Frauenerwerbstätigkeit und Dienstleistungsnachfrage privater Haushalte in der Bundesrepublik Deutschland, Jahrbücher für Nationalökonomie und Statistik, Bd. 211: 22-41.

Becker, G. S. (1960), An Economic Analysis of Fertility. Demographic and Economic Change in Developed Countries, NBER, Princeton: 209-231.

Becker, G. S./K. M. Murphy, and Tamura, R. (1990), Human Capital, Fertility and Economic Growth, Journal of Political Economy 98: 12-37.

Becker, G. S. (1981/1991), A Treatise on the Family, Harvard University Press.

Browning, Marin et al. (2011): Family Economics, Unpublished.

Becker, S./ Cinnirella, F., and Woessmann, L. (2009): The Trade-off between Fertility and Education: Evidence from before the Demographic Transition, Journal of Economic Growth, 2010, 15 (3): 177-204.

BFSFJ: Gender-Datenreport - 1. Datenreport zur Gleichstellung von Frauen und Männern in der Bundesrepublik Deutschland München, November 2005: 219. VDR-Statistik Rentenzugang. Can be downloaded at: http://www.bmfsfj.de

Bletzinger, M./U. Walz (1989), Zum Schattenpreis- und Einkommensbegriff in der ökonomischen Theorie der Fertilität, Jahrbücher für Nationalökonomie und Statistik, Bd. 206: 591-598 
Brentano, L. (1909), Die Malthus'sche Lehre und die Bevölkerungsbewegung der letzten Dezennien, in: Abhandlungen der historischen Klasse der Königlich-Bayerischen Akademie der Wissenschaften, Bd. 24, München.

Bundesinstitut für Bevölkerungsforschung 2011, Zusammengefasste Geburtenziffer in Deutschland, 1871 bis 2009. Can be downloaded at: http://www.bib-demographie.de

Cervellati, M., U. Sunde (2007), Human Capital, Mortality and Fertility: A Unified Theory of the Economic and Demographic Transition, IZA Discussion Paper No. 2905.

Coale, A.J., S.C. Watkins (1986), The Decline of Fertility in Europe, Princeton.

Destatis (2012a), Durchschnittliche und fernere Lebenserwartung nach ausgewählten Altersstufen, http://www.destatis.de/jetspeed/portal/cms/Sites/destatis/Internet/DE/Content/Statistiken/Bev oelke-

rung/GeburtenSterbefaelle/Tabellen/Content50/LebenserwartungDeutschland,templateld=rend erPrint.psml

Destatis (2012b), Durchschnittliche Kinderzahl je Frau, Zusammengefasste Geburtenziffer, http://www.destatis.de/jetspeed/portal/cms/Sites/destatis/Internet/DE/Content/Statistiken/Bev oelkerung/GeburtenSterbefaelle/Tabellen/Content50/GeburtenZiffer,templateld=renderPrint.psml

Dinkel, R. (1985), Nur Transfers zur Anpassung an den Bevölkerungsrückgang?, Stuttgart.

Ehmer, J. (2004), Bevölkerungsgeschichte und historische Demographie 1800-2000, (Enzyklopädie deutscher Geschichte, Bd. 71), München.

Esenwein-Rothe, I. (1978), Modelle für eine Bevölkerungsprojektion und die Grenzen ihrer Aussagekraft, Jahrbücher für Nationalökonomie und Statistik, Bd. 193: 54-83.

Fleury, M/Henry, L. (1956), Des registres paroissiaux à l'histoire de la population. Manuel de dépouillement et d'exploitation de l'état civil ancien, Paris.

Freedman, R. (1975), The Sociology of Human Fertility, New York.

Fürth, H. (1913), Der Rückgang der Geburten als soziales Problem, Jahrbücher für Nationalökonomie und Statistik, Bd. 100: 721-760.

Galor, O. (2005), From Stagnation to Growth: Unified Growth Theory. In: Aghion, P., Durlauf, S. (eds.), Handbook of Economic Growth, vol. 1A: 171-293, Amsterdam.

Galor, O., Weil, D. (1996), The Gender Gap, Fertility and Growth, American Economic Review 86: 374387.

Günther, E. (1931), Der Geburtenrückgang als Ursache der Arbeitslosigkeit? Untersuchung einiger Zusammenhänge zwischen Wirtschaft und Bevölkerungsbewegung, Jahrbücher für Nationalökonomie und Statistik, Bd. 134: 921-973.

Guradze, H. (1916), Säuglingssterblichkeit, Geburtenhäufigkeit, Eheschließungen und Gesamtsterblichkeit in Berlin während des Krieges, Jahrbücher für Nationalökonomie und Statistik, Bd. 52 (3): 548-554.

Hübler, O. (1991), Einkommensdiskriminierung von Frauen und geschlechtsabhängige Einkommensdeterminanten, Jahrbücher für Nationalökonomie und Statistik, Bd. 208: 607-624.

Hoffman, W. G./Müller, J. H. (1959), Das deutsche Volkseinkommen 1851-1957, Tübingen.

Kendzia, M. J./T. Pierenkemper (2010): Der vormoderne Allokationsprozess von Arbeit in Deutschland, IZA Discussion Paper No. 4962.

Kendzia, M. J. (2010a): Herausbildung erster Wesenszüge des Normalarbeitsverhältnisses in Deutschland, IZA Discussion Paper No. 5107.

Kendzia, M. J. (2010b): Der Institutionalisierungsprozess des Lohnarbeitsverhältnisses vom Ersten bis zum Zweiten Weltkrieg in Deutschland, IZA Discussion Paper No. 5231.

Kleinhenz, G. D. (2004), Bevölkerung und Wachstum: Die Bevölkerungsentwicklung in Deutschland als Herausforderung für die Wirtschafts- und Sozialpolitik, Jahrbücher für Nationalökonomie und Statistik, Bd. 224: 74-90.

Knapp, G. F. (1873a), Aenderungen der Sterblichkeit vom Jahre 1751 bis 1870, Jahrbücher für Nationalökonomie und Statistik, Bd. 22: 141-144.

Kohler, H. P. et al. (2002), The Emergence of Lowest-Low Fertility in Europe During the 1990s, Population and Development Review 28 (4): 599-639.

Kollmann, P. (1915), Zur Geburtenfrage, Jahrbücher für Nationalökonomie und Statistik, Bd. 104: 251253.

Kurz, R. (1982), Wirtschaftswachstum bei stagnierender und schrumpfender Bevölkerung, Jahrbücher für Nationalökonomie und Statistik, Bd. 197: 235 - 250. 
Mackenroth, G. (1934), Deutsche Industriepolitik 1933, Jahrbücher für Nationalökonomie und Statistik Zeitschriftenband, Bd. 140: 205-224.

Malthus, Thomas (1798), An Essay on the Principle of Population, London.

Mincer, J. (1963), Market Prices, Opportunity Costs and Income Effects: 67-82, in: C. F. Christ (ed.), Measurement in Economics, Stanford.

Michalke, O. (1935), Die Frauenarbeit, Jahrbücher für Nationalökonomie und Statistik, Bd.142: 435448.

N.N. (1871), Die Bevölkerung des deutschen Reiches nach der Volkszählung vom 1. December 1871 verglichen mit der Bevölkerung von 1867, Jahrbücher für Nationalökonomie und Statistik, Bd. 19: 135-137.

Notestein, F. W. (1945), Population - The Long View, in: T. W. Schultz (ed.), Food for the World, Chicago.

Oldenberg, K. (1923), Zusammenhang zwischen Geburtenhäufigkeit und Säuglingssterblichkeit, Jahrbücher für Nationalökonomie und Statistik, Bd. 120: 351 - 353.

OECD (2011), OECD Family database, Doing Better for Families Germany, Paris.

Overbeek, J. (1974), History of Population Theories, Rotterdam.

Pollack, R.A./S. C. Watkins (1993), Cultural and Economic Approach to Fertility: Proper Marriage or Mésalliance?, in: PDR 19: 467-496.

Prinzing, F. (1899), Die Entwickelung der Kindersterblichkeit in den europäischen Staaten, Jahrbücher für Nationalökonomie und Statistik, Bd. 72: 577-635.

Rohr (1891), Die Bevölkerung der deutschen Groß- und Mittelstädte, Jahrbücher für Nationalökonomie und Statistik, Bd. 57: 111-127.

Rostow, W. W. (1960), The Stages of Economic Growth: A Non-Communist Manifesto, Cambridge.

Schaich, E. (1998), Der Geburteneinbruch in den neuen Bundesländern seit 1990 und einige Hypothesen zu seiner Erklärung, Jahrbücher für Nationalökonomie und Statistik, Bd. 217: 93-107.

Scheel, H. von (1866), Untersuchungen über den Einfluss der Fruchtpreise auf die Bevölkerungsbewegung, Jahrbücher für Nationalökonomie und Statistik, Bd. 6: 161-185.

Scheel, H. von (1874), Frauenfrage und Frauenstudium, Jahrbücher für Nationalökonomie und Statistik, Bd. 22: 1-17.

Schultz, T. P. (2009), Population and Health Policies, IZA Discussion Paper No. 4340, Bonn.

Seutemann, K. (1906), Die Hauptergebnisse der Volkszählung im Deutschen Reiche vom 1. Dezember 1905, Jahrbücher für Nationalökonomie und Statistik, Bd. 87: 81-91.

Seutemann, K. (1907), Der Stand der Statistik der Bevölkerungsbewegung im Deutschen Reich und die Hauptzüge der Bevölkerungsentwicklung in den letzten 15 Jahren, Jahrbücher für Nationalökonomie und Statistik, Bd. 88: 289-313.

Statistisches Bundesamt (2008), Arbeitskräfteerhebung der EU, (Hrsg.) Bundeszentrale für politische Bildung.

Thompson, W. S. (1929), Population, American Journal of Sociology, 34(6): 959-975.

Ungern-Sternberg, R. von (1937), Wirtschaftliche Konjunktur- und Geburtenfrequenz, Jahrbücher für Nationalökonomie und Statistik, Bd. 145: 471-488.

Wagner, A. (1980), Der Geburtenrückgang als Ursache von Arbeitslosigkeit? Einige Bemerkungen zum Günther-Paradoxon, Jahrbücher für Nationalökonomie und Statistik, Bd. 195.

Wagner, A. (1985): Nur Transfers zur Anpassung an den Bevölkerungsrückgang?, Jahrbücher für Nationalökonomie und Statistik, Bd. 200: 542-550.

Zimmermann, K. F. (1985), Familienökonomie, Berlin u.a.O.

Zimmermann, K. F. (1988), Wurzeln der modernen ökonomischen Bevölkerungstheorie in der deutschen Forschung. Jahrbücher für Nationalökonomie und Statistik, Bd. 205: 116-130.

Zimmermann, K. F. (1989), Die Konkurrenz der Genüsse: Ein Brentano-Modell des Geburtenrückgangs. Zeitschrift für Wirtschafts- und Sozialwissenschaften (ZWS), Bd. 109: 467-483.

Zwiedineck-Südenhorst, O. von (1941), Psychologie und Biologie in der Ausdeutung der Geburtenstatistik, Jahrbücher für Nationalökonomie und Statistik, Bd. 145: 160-176. 